\title{
Re-understanding the Process Law of Ideological and Political Education
}

\author{
Jiangfeng Li \\ Zhengzhou Normal University Henan China \\ Sz2008peak@163.com
}

Keywords: Ideological and political education, Law of process, Essential links.

\begin{abstract}
The academic circles have different opinions on the understanding of the law of ideological and political education. Through further combing the views of all parties, it is conducive to in-depth discussion of the law of ideological and political education process, to find the essential links between various factors in the process of ideological and political education, and then deepen the understanding of the procedural law of ideological and political education.
\end{abstract}

\section{Introduction}

The process law of ideological and political education is an important component of the theoretical system of ideological and political education, and it is one of the important issues in the research of basic theory of ideological and political education. Focusing on this topic, many scholars have launched a multi-dimensional inquiry, mainly related to the law system of ideological and political education, the basic law of ideological and political education, the process law of ideological and political education, and the law of the operation of the subject of ideological and political education, the ideological development law of the object of ideological and political education, the law of developing method of ideological and political education, the law of carrier development of ideological and political education, etc. The research on the law of ideological and political education has a direct influence on the educational practice in theoretical circle, and the regular discourse plays an important role in the discourse system of ideological and political education. In the daily education activities, these discourse forms have become the lingua franca, such as "respecting the laws of ideological and political education", "following the laws of ideological and political education" and "acting according to the laws of ideological and political education", which have become important forms of the ideological and political education discourse system. Among them, the basic law of ideological and political education is the core, which is one of the most basic theoretical issues, and it is also the major issue that academic circles should give general attention and need further study. Scientific revelation, in-depth research and exploration of the basic laws of ideological and political education have a strong role in promoting the construction and development of the ideological and political education discipline. At the same time, it has certain application value for the smooth development of ideological and political education practice and the enhancement of actual effect. However, so far, although many scholars have discussed the basic law of ideological and political education process, and got some constructive theoretical achievements, the academic circle has not reached a consensus understanding, there are different opinions and arguments. This requires us to fully analyze the characteristics and the contradictory movement process of ideological and political education on the basis of combing the existing research achievements in the academic field, to explore the most essential relationship among the elements and characteristics of ideological and political education - the basic law.

\section{Different Understanding of the Basic Law of Ideological and Political Education Process}

At present, academic circles have different understanding or different views about the basic law of ideological and political education process, and even big gaps exist between some views, which directly affect the development of ideological and political education discipline and the implementation of educational activities. At present, the main viewpoints of academic circles are as 
follows: firstly, the basic law of ideological and political education process is defined directly as the law of ideological and political education. Some scholars believe that the law of ideological and political education is a system, as for the ideological and political education itself, the basic law of the ideological and political education process is the basic law of ideological and political education. The law of ideological and political education is a system. This basic law is referred to as "the law of adaptability and elevation". Among them, the law of bidirectional interaction, the law of internalization and externalization and the law of coordination and control have the global significance. Some scholars believe that ideological and political education is developed and realized in the process of contradictory movement, which is bound to have certain regularity and the basic trend of its development. The basic laws running through the whole process and various aspects of ideological and political education are: the law of directed guidance in conflict, the law of development in twists and turns, and the law of hierarchy progression. Other scholars completely equate the basic law of ideological and political education with the basic law of the ideological and political education process, that is, the basic laws of ideological and political education are the law of social adaptation, the law of coordination of elements, the law of sufficient process, the law of personality analysis and the law of self-identity; however, the law of the same content was defined as the basic law of the ideological and political education process in his later research. This change seems to mean a revision of his original understanding.

The above views either define the basic laws of ideological and political education from the perspective of the ideological and political education process, or completely equate the basic laws of the ideological and political education process with the basic laws of ideological and political education, they all mean that the researchers are fully aware of the position and effect of the ideological and political education process in the ideological and political education; while some scholars divide the law of ideological and political education into different levels, and give a concrete overview of the practice of each level, which is reasonable and more worthy of affirmation. But on the whole, whether the process law of ideological and political education can include all the laws of ideological and political education needing to be researched, and it is more debatable of the views which directly equate the basic law of the process with the basic law of ideological and political education.

\section{Re-understanding of the Process Law of Ideological and Political Education}

The process law of ideological and political education should be further discussed from the following aspects.

First of all, whether the "adaptation to the law of transcendence" can be regarded as the basic law of ideological and political education is worthy of reflection and research. The object of "adaptation and transcendence" is controversial, whether it is the ideological character of the educated or its ideological and political condition. Besides, it cannot be done at the same time. The task of ideological and political education is to improve or transform the thoughts of the educated and improve their ideological and political quality. If adapted enough, it is difficult to surpass or even impossible to achieve. Imagine how to adapt to the education of a very secularized, low-moral person? It is doubtful whether it will be possible to transcend these after adaptation. Certainly, it does not mean that the ideological situation of the educated does not need to be taken into account in the process of education. In fact, a full understanding of the ideas of the educational object is the prerequisite for the implementation of education, and it is one of the key factors for the success of education. But the problem is that understanding is not equal to adaptation. On the basis of understanding, we should carry out the education according to the ideological situation of the educational object, and finally realize the transformation, consolidation or promotion of the thought.

Secondly, whether it is the process of understanding ideological and political education or the operational process of revealing the law of ideological and political education, they are all the important link to study the basic law of ideological and political education. However, it is somewhat narrow and far-fetched to think that the law of ideological and political education is a process of 
"choice-absorption -internalization". Indeed, the whole process of ideological and political education should follow the law of ideological and political education, otherwise it is impossible to achieve the purpose of education and educational effect. The educational process is the carrier of the educational law, although people's understanding of the educational law is summed up or concluded through the understanding of the educational process, the two are not the same thing. Moreover, the process is only a part of the ideological and political education, it is only a stage in the operation of the ideological and political education itself, and it cannot cover the essence, purpose and all other factors of ideological and political education. There are, of course, some scholars believe that the law of directed guidance in conflict, the law of development in twists and turns, and the law of hierarchical progression are all the basic laws of ideological and political education based on the contradictory movement in the process, this perceive is of positive significance. This view recognized the existence of contradictions and conflicts in ideological and political education, and it is realized that ideological and political education develops and advances in the process of guiding the alleviation and resolution of contradictions and conflicts with ups and downs in accordance with certain aims and plans.

Finally, the law of social adaptation, the law of coordination of elements, the law of sufficient process, the law of personality analysis, the law of self-identity, etc., those have exemplary significance for the study of the basic laws of ideological and political education. However, whether it can fully express the basic law of ideological and political education, it remains to be further discussed. As for "the law of social adaptation", "the law of coordination of elements" and "the law of sufficient process", every practical activity of mankind to achieve its objectives and its effectiveness are all necessary to adapt to the needs of social development and require the coordination among the elements in order to form the resultant force. It is necessary to satisfy the four conditions of cognition, affection, thought and behavior in the process of practice, so as to achieve the aim of "enlightening with reason, responding with emotion, guiding with action and doing things with perseverance".

\section{Summary}

In fact, whether it is an important component of ideological and political education, or the core part of a single educational activity, this process consists of subject, object, content of education, carrier of education, environment of education and so on. In the operation of ideological and political education, any constituent factors are functioning, and any components are not dispensable. These factors must have one kind or another relation and even produce contradictions among each other. How to straighten out the relationship between them and ensure the smooth implementation of educational activities is the key to the success of education. However, it must be made clear that the importance of the various factors and their departments should be emphasized in order to remind people of the importance of any participation factor, not to be disregarded by its low position, not to be singled out by its high position, so as to form the resultant force of participating factors and effect exertion to ensure the achievement of educational goals. To explore the basic process law of the ideological and political education is to find the essential relation between various factors in the operational process of ideological and political education.

\section{References}

[1]. Luo hongtie, The Review and Prospect of Research on the Law of Ideological and Political Education, Studies in Ideological Education, Vol.163 issue1 PP.3-7,2009

[2]. Zou shaoqing, An Analysis of the Law of Ideological and Political Education Process, The oretical investigatton, Vol.145, PP.120-124, 2008

[3]. Fei ping, Historical Analysis and Future Prospect of Research on the Law of Ideological and Political Education Process, Ideological and Political Education Research, Vol.29, PP.43-46,2013 
[4]. Zhao yetian, A Survey of the Research on Ideological and Political Education Process, Ideological and Political Education Research, Vol.25, PP.23-32,2009 